\title{
Highwall Mining Stability
}

\author{
Baotang Shen ${ }^{1,2}$ \\ ${ }^{1}$ CSIRO Energy Flagship, Pullenvale, Brisbane, Australia \\ ${ }^{2}$ State Key Laboratory of Mining Disaster Prevention and Control, Shandong University \\ of Science and Technology, Qingdao, China
}

\begin{abstract}
Highwall mining is a remotely controlled mining method which extracts coal from the base of an exposed highwall. The method has the advantage of low capital cost and less lead time compared with a full underground mine, while being capable of producing in excess of 1 million tonnes per system per year. This method has been used in Australia, USA and India with considerable success.

Pillar/panel stability and span stability are two major geomechanical issues for highwall mining. Comprehensive studies in these areas have been conducted in Australia. Innovative theoretical and numerical developments, together with comprehensive site monitoring and case studies, have been performed. These studies have significantly improved the understanding of how rocks and coal respond to highwall mining, and so have helped to improve the layout design for better coal recovery with less risk Apart from the significant success of using this method to mine millions of tonnes of coal, a number of major roof/panel failures have been experienced.
\end{abstract}

This paper provides an overview of the highwall mining technology. A detailed case study on a panel failure is also presented.

Keywords: Highwall mining, panel stability, pillar, span.

\section{Introduction}

Highwall mining is a remotely controlled mining method which extracts coal from the base of an exposed highwall, typically via a series of parallel entries driven to a significant depth within the seam horizon (Figure 1). The method allows recovery of coal from surface pits that have reached final highwall position, or in areas where coal has become sterilized in, for example, service corridors. Highwall mining is a hybrid system capable of accessing these reserves for substantially less capital cost and lead time than a full underground mine, while being able to produce over 1 million tonnes per year per system. Highwall mining also has a significant operating cost advantage over underground mining, because it is less labour intensive.

The current highwall mining systems originated in the USA in the mid-1970's. They have been used for commercial mining since the early 1980's in the USA. These technologies were first introduced into Australia in 1989. Commercial highwall mining operations in Australia started two years later in early 1991. Since 1991, highwall mining has been used in over 30 pits at 13 coal mines in Australia. 


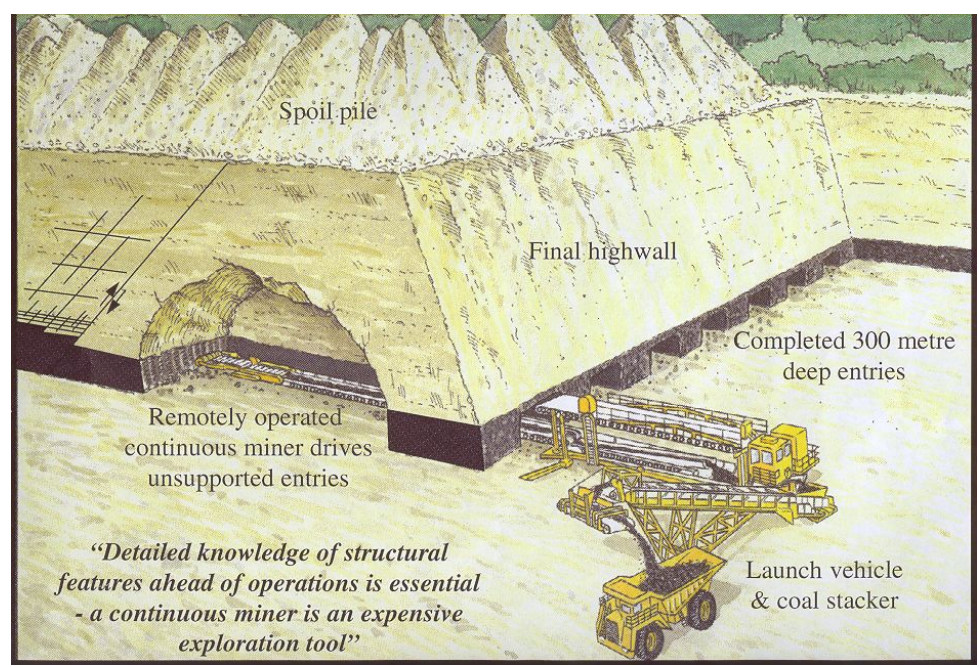

Figure 1. A schematic image of highwall mining operation.

Two types of highwall mining systems have been used. They are the Continuous Highwall Mining System (CHM) which mines rectangular entries usually about $3.5 \mathrm{~m}$ wide (Figure 2) and the Auger System which creates individual or twin circular holes of various diameters (Figure 3). The CHM has been much more widely used than augers because of its advantage in productivity and recovery rate. In one of the Australia coal mines, a CHM system has routinely reached $500 \mathrm{~m}$ penetration distance into the coal seam from the base of the highwall and has achieved a maximum production rate of 124,000 tonnes per month. In comparison, an Auger system can often reach $200 \mathrm{~m}$ penetration and produce up to 60,000 tonnes per month. However, its disadvantage in recovery rate and productivity is offset by its tolerance of difficult geological conditions. This makes it more suitable for highwall mining of a pit with unfavourable roof and floor conditions.

\section{Geomechanical issues associated with highwall mining}

Three major geomechanical issues are associated with highwall mining (Shen and Duncan Fama [1]). They are:

Highwall stability

Highwall stability is essential to ensure the safety of mining personnel and equipment as the mining operation is beneath the highwall. A final highwall is often 40-60 $\mathrm{m}$ deep and dips at $>70^{\circ}$. In most cases, the final highwall is created by pre-split blasting so as to reduce highwall hazards.

Highwall instabilities can be broadly classified into three categories based on their scales. They are: 1) Mass instability: deep seated movement of rock mass into the pit, caused by subsidence or major faulting. 2) Face instability: failure at the highwall face due to incomplete pre-split blasting or joints parallel to the highwall

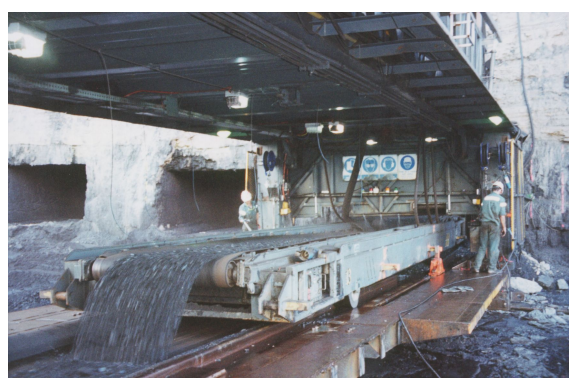

Figure 2. A Continuous Highwall Mining System (CHM) in operation. 
face. 3) Block instability: localised falls of rock blocks or wedges from the highwall face at various sizes.

The highwall mining system has a basic protection shield built above the working area in the launch vehicle. The shield reduces the risk of damage or injury caused by small block falls from the highwall face. The shield cannot provide protection from larger block falls or mass highwall instability. So it is necessary to identify the risk of any highwall instability before mining and take proper preventive measures during mining.

As part of the highwall mining design procedure, a highwall stability assessment is commonly conducted by means of highwall mapping. Highwall mapping should identify any potential face or block instability. A hazard map is then produced to help mining operators to take preventive measures during mining, such as personnel staying a minimum distance away from the highwall face, or abandoning a dangerous section of the pit. Mass instability is very rare except when caused by a panel failure after mining.

\section{Pillar/panel stability}

Pillars are left in between the highwall entries to support the overburden during and after highwall mining. Stable pillars are essential for a successful highwall mining operation. If the pillars collapse during mining, the overburden will cave into the mining entry and may jam the mining equipment. This often results in a loss of the equipment. At least 7 such incidents have occurred in Australia. The incidents have caused significant loss of mining equipment and minable resource.

Pillar design is the key part of a highwall mining layout design. An optimal pillar size and entry layout aims for maximum recovery at an acceptable risk. An overoptimistic design poses too much risk for mining personnel and equipment, whereas over-conservative design causes unnecessary loss of resource.

An optimal layout design requires good understanding of pillar failure mechanisms and accurate estimates of coal strength and other geological parameters which determine the pillar

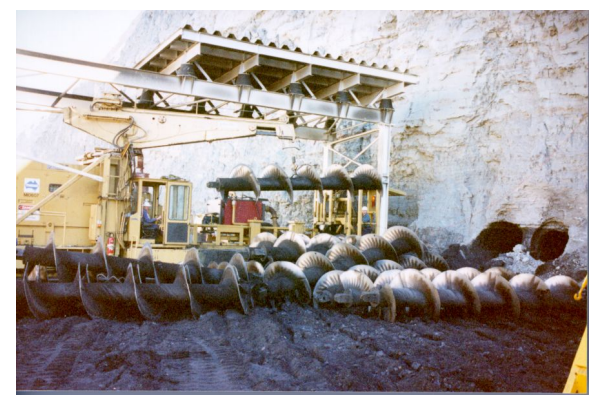

Figure 3. An Auger System in

operating strength.

\section{Span stability}

The highwall entries are mined by a remotely controlled mining system and they are unmanned and unsupported. A key prerequisite for successful highwall mining is stability of the unsupported spans, at least within a period of days or weeks, when the mining equipment is in or close to the entry. Span stability is more a concern for the CHM method than for the Auger method. A CHM system creates rectangular entries with a span width usually $3.5 \mathrm{~m}$, whereas an Auger system creates an arched roof with an effective span of often less than $1.0 \mathrm{~m}$ (or half of the auger diameter). Both systems can tolerate some minor roof falls, i.e. $<0.1 \mathrm{~m}$ in thickness. Excessive roof falls, however, can damage and, in extreme cases, even bury the equipment. The CHM system is particularly vulnerable to major roof falls.

Span stability assessment is required prior to the commencement of highwall mining in a given pit. An accurate forecast of span conditions will help the mining operators to identify the potential hazards and hence take remedial measures to 
prevent roof falls, such as leaving coal in the roof.

\section{Case study of a panel failure}

A highwall mining trial was conducted in Pit B at Mine A in late 1997 to assess possible full-scale deployment of highwall mining in the mine.

Pit B is a highwall block bounded to the south and west by regional faults. A total highwall length of about $550 \mathrm{~m}$ is available for mining, including an angled end forming the northern pit boundary (Figure 4). The mining operations in Pit B were conducted using a CHM system. A total of 67 entries were mined in this pit in a time span of about 6 weeks. The penetration distance achieved was on average about $100 \mathrm{~m}$, far shorter than the planned maximum penetration depth of $350 \mathrm{~m}$. Various problems including roof falls, soft floor, and gas problems contributed to the poor performance. Despite these problems, the highwall mining panels were observed to be stable during mining.

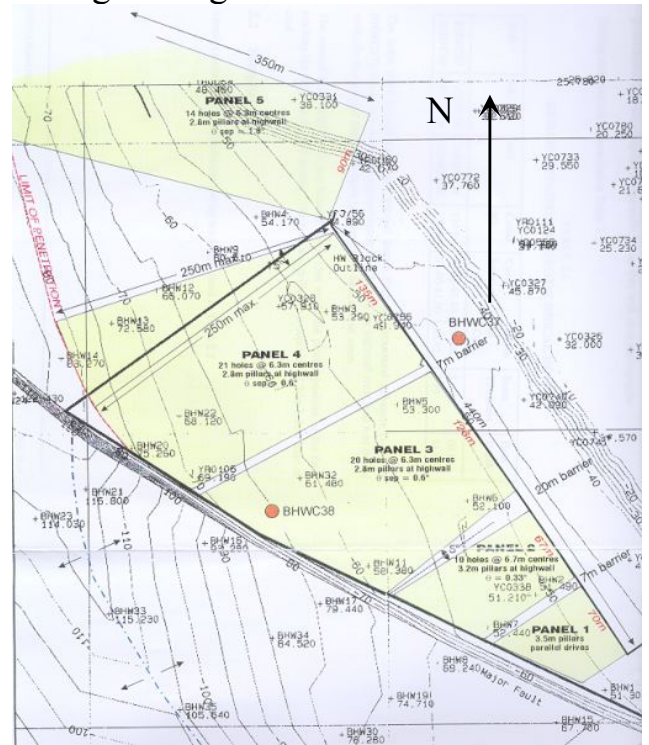

Figure 4. Highwall mining panels and design specifications, Pit B, Mine A.

The mining operations stopped after completion of Entry 67 . The pit gradually filled with water after the pit was closed, and by August 1998, all mined entries were submerged in water.

On the 12th of January 1999, a localised panel failure occurred in the middle section of the pit (Figure 5). The failure extended about $80 \mathrm{~m}$ along the highwall and $50 \mathrm{~m}$ into the highwall. The whole process of failure took about 5 minutes. The subsidence was fully developed in a period of two weeks.

\subsection{Pit Geology and mining record}

Pit B highwall has a SE-NW orientation, and it extends about $455 \mathrm{~m}$ in total. The height of the highwall is about $50 \mathrm{~m}$. There is a bench about $15 \mathrm{~m}$ wide $10 \mathrm{~m}$ below the top of the highwall. The overburden stratigraphy is typical Rangal Coal Measure sedimentary sequence comprising clayey siltstones, massive to well-bedded, with sub-dominant labile fine grained sandstones and claystone. A simplified core $\log$ is shown in Figure 6. The immediate roof comprises a $0.8 \mathrm{~m}$ thick claystone, silty, weak to moderately strong, and is gradational with coal at the fused roof contact. Bedding planes in the roof strata are planar and rough. Bed thickness in the roof is $10 \mathrm{~cm}$ to $35 \mathrm{~cm}$. In the area of failure, roof bedding planes are observed to dip toward the seam at an angle of approximately $15^{\circ}$.

The seam has an average thickness of about $4 \mathrm{~m}$. It dips to SE with an average dip angle of $8^{\circ}$. The seam comprises dull, to dull and bright banded compositions in roof and floor plies for a thickness of about $0.8 \mathrm{~m}$. The central seam is bright banded. A weak, carbonaceous mudstone band, about $0.02 \mathrm{~m}$ in thickness, occurs about $0.4 \mathrm{~m}$ below the seam roof.

The most significant structural feature in this pit is the relatively frequently occurring planar slickensided joints observed in the upper to mid plies of the coal seam. The joints dip about $35^{\circ}$ to the south along the highwall. The intensive 
coal joints are persistent within the seam and most of them extend to the roof and floor.

Highwall mining operations started from the southern end of the pit and progressed to the north. The whole reserve was mined in four panels (see Figure 4). Panel
Barrier pillars were left between panels. The size of the barrier pillar at the highwall was $7 \mathrm{~m}, 13 \mathrm{~m}$ and respectively between panels $1,2,3$ and 4 .

A total of 67 entries were mined. The penetration depths of the entries are shown in Figure 7. Frequent roof falls

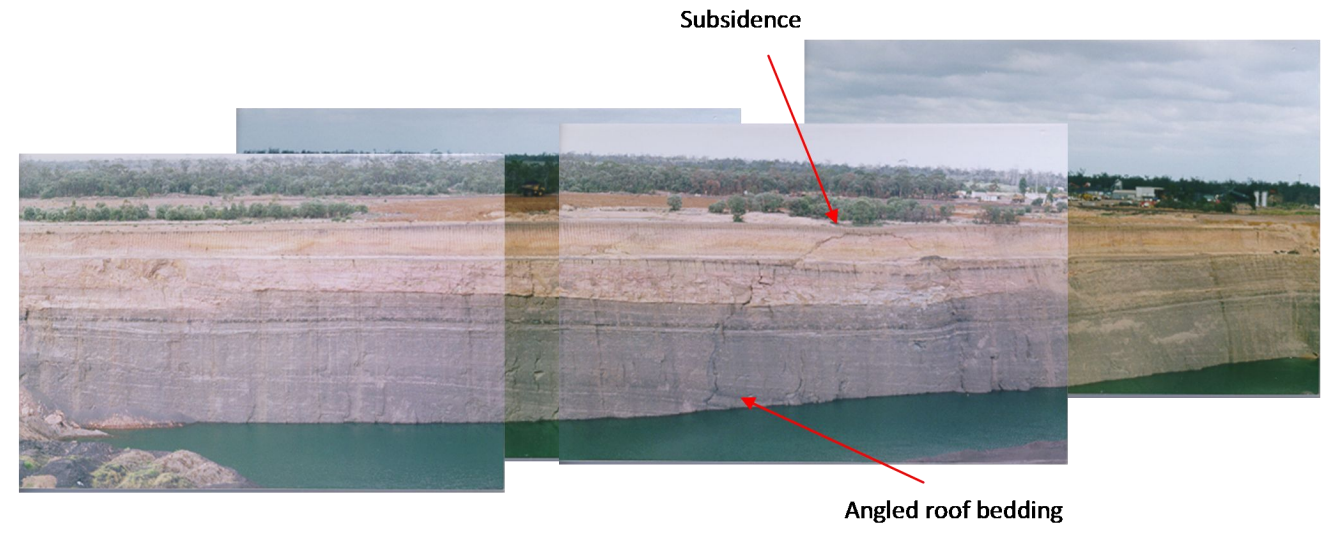

Figure 5. Highwall face and a panel failure at the mid section of the highwall, Pit B. Angled roof bedding planes are noticed at the area of failure

Siltstone $25 \mathrm{~m}$

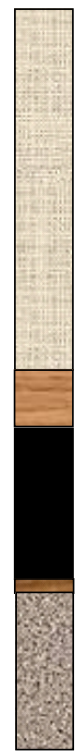

End of drillhole

Figure 6. A simplified core log of the roof and floor geology in Pit B.

5 shown in Figure 4 was not mined. The pillar size and layout as designed and used in each panel are listed in Table 1. occurred in Entry 43 and the subsequent entries. As mining advanced the roof falls occurred closer to the highwall. The roof fall problem appeared to have been associated with the change in bedding planes from parallel to the seam to dipping down onto the seam, as indicated in Figure 5. It should be emphasized that major roof falls occurred in entries from \#43 onward. The subsided area appears to be right behind the area where major roof falls occurred during mining.

\subsection{Back-analysis of the observed panel failure}

It is surprising that the subsidence occurred right above a barrier pillar, although this barrier pillar narrowed to close to the normal pillar width at about $50 \mathrm{~m}$ inbye. Limit Equilibrium Method and numerical tool UDEC analysis were used in the back-analysis. UDEC models were used to investigate the stresses under the highwall, span stability, and the strength of pillars of different widths. 
Limit Equilibrium Method was used to evaluate the FOS of the panel. In the numerical models, the simplified geology shown in Figure 6 was used, except that the thin mudstone floor was modeled as a weak interface. modeling, these material properties have been estimated mainly based on geological descriptions and previous modeling experience. The material properties used in this study are listed in Table 3.

Table 1. Designed highwall mining layout

\begin{tabular}{|c|c|c|c|}
\hline Panel No. & Layout & Pillar width at highwall & Entry Nos. \\
\hline 1 & Parallel entries & $3.5 \mathrm{~m}$ & $1-10$ \\
\hline $\mathrm{Fa}$ & Fanned layout with a radial angle of $0.33^{\circ}$ & $3.0 \mathrm{~m}$ & $11-20$ \\
\hline $\mathrm{Fa}$ & Fanned layout with a radial angle of $0.58^{\circ}$ & $2.8 \mathrm{~m}$ & $21-40$ \\
\hline $\mathrm{Fa}$ & Fanned layout with a radial angle of $0.58^{\circ}$ & $2.8 \mathrm{~m}$ & $41-67$ \\
\hline
\end{tabular}

\subsection{Coal strength, rock properties and in situ stresses}

In situ stresses

\section{Coal strength}

Seven core samples from Pit B had been tested for the uniaxial compressive strength (UCS) and elastic modulus. Results are summarized in Table 2.

It is known that the in situ pillar strength on mass is much less than that of samples in laboratory size due to size effect. The mass coal strength for the coal seam is estimated using the CSIRO's method to be 3.0MPa. This is compared with a mass UCS of $3.6 \mathrm{MPa}$ used in the design. Note that a mass coal UCS is the uniaxial compressive strength of a cylindrical coal mass. It differs from the cubic mass coal strength which is more widely used in literature. It has also been reported that the mass coal UCS is typically $20-30 \%$ less than the cubic strength (Townsend, et al [2]).

The intensive and inclined coal joints in the seam may have had a significant effect on pillar strength. They were considered in the original design and have been considered in this study as well.

Rock properties

The strength and elastic properties of roof and floor rocks have not been tested, nor were any interface or joint properties available. For the purpose of numerical
Stress measurements were not carried out at this mine. In this study, it was assumed

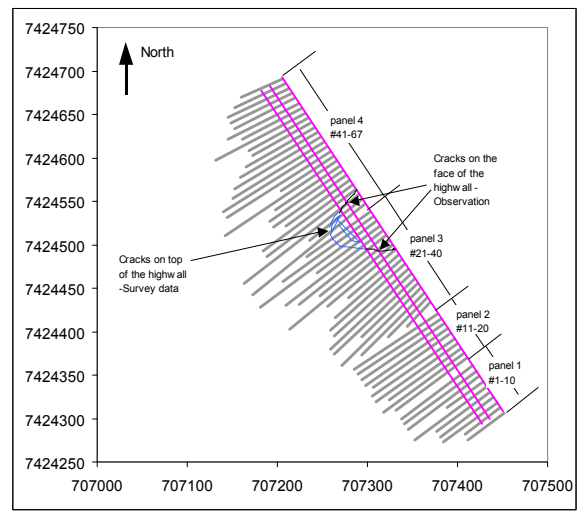

Figure 7. Highwall mined entries, and the surface cracks after subsidence hased on survev and ohservation that the ratio of principal horizontal stress to vertical stress was $\sigma_{\mathrm{h}} / \sigma_{\mathrm{v}}=0.33$ in the direction parallel to the highwall, and $\sigma_{\mathrm{H}} / \sigma_{\mathrm{V}}=1.0$ perpendicular to the highwall, as it is close to the normal direction of the regional fault. These stress ratios were assumed to be the same in both coal and other rocks, prior to the excavation of the highwall. 
Table 2. Laboratory test results of 7 coal samples from Pit B.

\begin{tabular}{|c|c|c|c|c|c|c|c|}
\hline $\begin{array}{c}\text { Sampl } \\
\text { e No. }\end{array}$ & $\begin{array}{c}\text { Sample } \\
\text { depth } \\
(\mathrm{m})\end{array}$ & $\begin{array}{c}\text { Diamet } \\
\text { er } \\
(\mathrm{mm})\end{array}$ & $\begin{array}{c}\text { Length } \\
(\mathrm{mm})\end{array}$ & $\begin{array}{c}\text { Density } \\
\left(\mathrm{Kg} / \mathrm{m}^{3}\right. \\
)\end{array}$ & $\begin{array}{c}\text { UCS } \\
(\mathrm{MPa} \\
)\end{array}$ & $\begin{array}{c}\text { Young's } \\
\text { modulus } \\
(\mathrm{MPa})\end{array}$ & $\begin{array}{c}\text { Poisson } \\
\text { 's ratio }\end{array}$ \\
\hline $37-3$ & $\begin{array}{c}54.11- \\
54.32\end{array}$ & 62.8 & 83.0 & 1400 & 13.9 & 3734 & 0.51 \\
\hline $37-4$ & $\begin{array}{c}54.32- \\
54.69\end{array}$ & 62.9 & 161.3 & 1391 & 2.9 & 2461 & 0.28 \\
\hline $37-5$ & $\begin{array}{c}55.13- \\
55.43\end{array}$ & 62.5 & 162.5 & 1378 & 5.9 & 2901 & 0.39 \\
\hline $37-6$ & $\begin{array}{c}56.13- \\
56.43\end{array}$ & 62.8 & 161.4 & 1384 & 11.6 & 3591 & 0.44 \\
\hline $38-3$ & $\begin{array}{c}66.04- \\
66.28\end{array}$ & 62.5 & 89.0 & 1608 & 7.4 & 3739 & \\
\hline $38-4$ & $\begin{array}{c}66.94- \\
67.16\end{array}$ & 62.7 & 110.6 & 1391 & 6.5 & 1760 & 0.30 \\
\hline $38-5$ & $\begin{array}{c}68.35- \\
68.61\end{array}$ & 63.0 & 120.1 & 1325 & 7.0 & 1887 & 0.30 \\
\hline
\end{tabular}

Table 3. Geomechanical input parameters for numerical modelling.

\begin{tabular}{|c|c|c|c|c|c|c|}
\hline & $\begin{array}{c}\mathrm{E} \\
(\mathrm{GPa})\end{array}$ & $v$ & $\begin{array}{c}\text { Cohesion } \\
(\mathrm{MPa})\end{array}$ & $\begin{array}{c}\phi \\
\left({ }^{\circ}\right)\end{array}$ & $\begin{array}{c}\sigma_{\mathrm{t}} \\
(\mathrm{MPa})\end{array}$ & $\begin{array}{c}\text { Mass UCS } \\
(\mathrm{MPa})\end{array}$ \\
\hline Coal & 2.0 & 0.37 & $\begin{array}{c}\text { Hoek-Brown } \mathrm{m}=2.93, \mathrm{~s}= \\
0.075, \sigma_{\mathrm{c}}=16.2 \mathrm{MPa}, \mathrm{a}= \\
0.65\end{array}$ & & 3.0 \\
\hline Siltstone & 4.0 & 0.25 & 1.3 & 35 & 0.5 & 5.0 \\
\hline Claystone & 2.5 & 0.25 & 1.04 & 35 & 0.4 & 4.0 \\
\hline $\begin{array}{c}\text { Coal/roof/f } \\
\text { loor } \\
\text { interfaces }\end{array}$ & & 0.012 & 16 & 0 & \\
\hline $\begin{array}{c}\text { Other } \\
\text { interfaces }\end{array}$ & & 0.5 & 30 & 0 & \\
\hline Coal joints & & 0.1 & 33 & 0 & \\
\hline Rock joints & & 0 & 30 & 0 & \\
\hline
\end{tabular}


Table 4. Pillar strengths for various conditions, predicted by numerical modeling.

\begin{tabular}{|c|c|c|c|}
\hline \multirow[b]{2}{*}{$\begin{array}{l}\text { Pillar width } \\
\text { (m) }\end{array}$} & \multicolumn{3}{|c|}{ Pillar strength $(\mathrm{MPa})$} \\
\hline & $\begin{array}{l}\text { Case } 1 \text { (height } \\
=2.8 \mathrm{~m})\end{array}$ & $\begin{array}{c}\text { Case } 2 \\
\text { (height }=4.8 \mathrm{~m} \text { ) }\end{array}$ & $\begin{array}{c}\text { Case } 3 \text { (height }=4.8 \mathrm{~m}, \\
\text { weaker coal joints) }\end{array}$ \\
\hline 2.8 & 3.2 & 3 & 2.2 \\
\hline 3.2 & & & 2.2 \\
\hline 3.7 & 4.8 & 3 & 2.6 \\
\hline 4.4 & 6.1 & 4.2 & 3.3 \\
\hline 7.0 & & 5.2 & 4.1 \\
\hline
\end{tabular}

\subsection{Stresses in the vicinity of the highwall}

Previous studies (Kelly et al. [3], Duncan Fama et al.[4]) suggest that stress concentration could occur near the highwall face due to the effect of an overlaying bench, and could lead to elevated stress in the coal seam beneath the bench. The possibility of a high stress in Pit B was investigated. A 2D numerical model simulated a cross section perpendicular to the highwall prior to highwall mining extraction. The highwall profile in the area of subsidence was used. In this model, intact rocks and coal were modeled as elastic materials, and their properties are listed in Table 3. All interfaces and joints except for the coal/roof and coal/floor interface were assumed to have a friction angle of $30^{\circ}$ and cohesion of $0.5 \mathrm{MPa}$. The roof and floor interface was assigned a friction angle of $16^{\circ}$ and cohesion of $0.012 \mathrm{MPa}$. The Pit B highwall appears to be smooth and free from major fractures. Therefore no blast damage was included in the model.

The stress model is shown in Figure 8. The predicted vertical stress at the midheight of the seam is plotted in. The maximum principal stress is also plotted in the figure. At the toe of the highwall, a vertical stress of $0.87 \mathrm{MPa}$ and a maximum principal stress of $1.05 \mathrm{MPa}$ are predicted. The maximum principal stress is predicted to be higher than the vertical stress within a penetration distance of
$70 \mathrm{~m}$. The vertical stress appears to be increasing gradually with the penetration distance, whereas the maximum principal stress reaches a local peak of $1.5 \mathrm{MPa}$ at $40 \mathrm{~m}$, where the vertical stress is $1.25 \mathrm{MPa}$. At penetration depths greater than $70 \mathrm{~m}$, the two stresses are generally the same, indicating that the disturbance to stress field due to the highwall excavation diminishes away from the highwall.

Because the maximum principal stress is not in the $2 \mathrm{D}$ vertical cross section, its effects on the results obtained by a 2D study are uncertain. To consider the unknown effect from the out-of-plane principal stress on the results of a $2 \mathrm{D}$

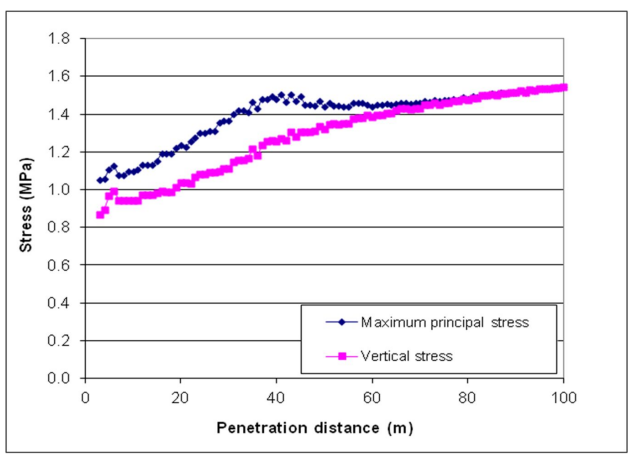

Figure 9. Numerically predicted vertical stress and maximum principal stress in the coal seam in the vicinity of the highwall.

analysis, both the vertical stress and the maximum principal stress as obtained in this $2 \mathrm{D}$ section were used. 


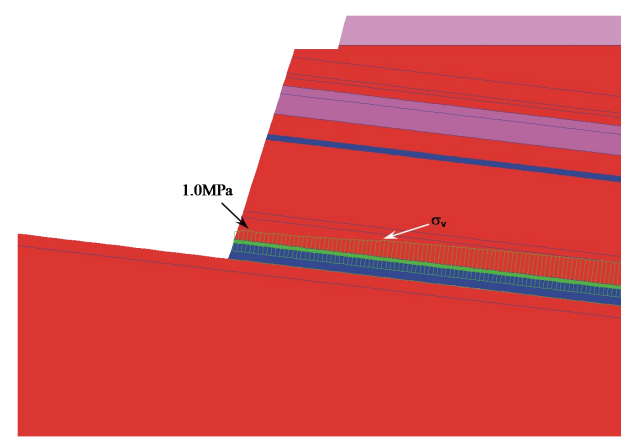

Figure 8. A 2D model to study the stresses near the highwall. The vertical stress is plotted.

\subsection{Span stability}

The stability of a highwall mining entry span was investigated using a UDEC model. Two cases were studied and compared: (1) when the bedding partings in the roof claystone were horizontal, and (2) when the roof bedding partings dipped at $15^{\circ}$ toward the seam. In both cases, the full seam height was assumed to have been mined so that the bedded claystone is exposed at the immediate roof. Vertical joints in the claystone layer were modelled at a spacing of $3.5 \mathrm{~m}$.

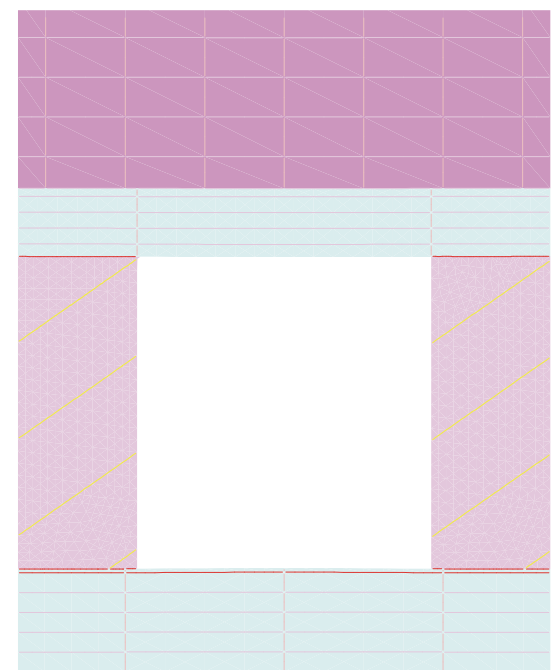

(a) Horizontal roof bedding their self-weight are predicted to be stable, and hence the span is predicted to be stable. When the bedding dips toward the seam at an angle, the layers behave as cantilever beams, and in this case the span is predicted to be unstable.

Roof falls are expected to be more severe at a shallow penetration depth near the highwall. This is because (1) the rock mass near the highwall often suffers disturbance, and (2) the confining stress in the direction perpendicular to the highwall is low. No evidence of more frequent roof falls, close to highwall has been recorded in this pit during mining. However, most of the roof falls are expected to occur after mining, particularly after the entries have been filled with water.

\subsection{Pillar strength}

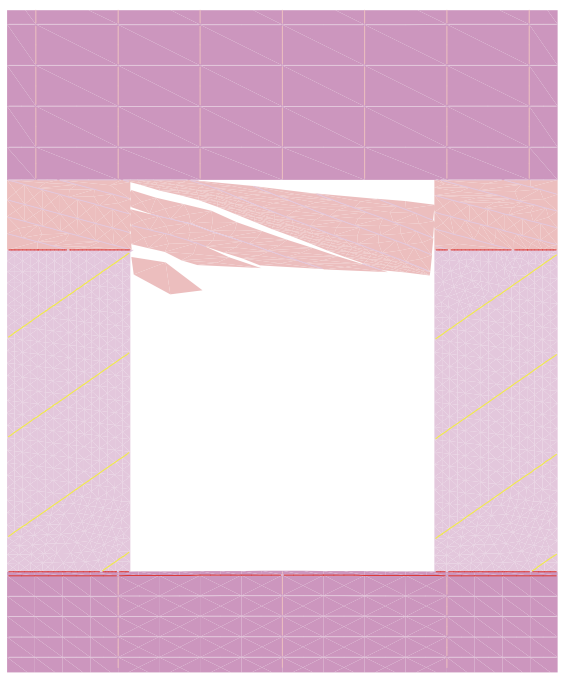

(b) Inclined roof bedding

Figure 10. Stable and unstable spans for horizontal and angle roof bedding, numerical predictions.

Figure 10 shows a comparison of modelled roof stability for the two cases. When the bedding planes are parallel to the seam, the layers act as fixed-end or simply supported beams after delamination. The beams mainly under
Within the subsided region there were both the regular pillars and a barrier pillar. The barrier pillar had a width of $7 \mathrm{~m}$ at the highwall and narrowed to $3.9 \mathrm{~m}$ at a penetration depth of $50 \mathrm{~m}$, based on the design. The regular pillars ranged from 
$2.8 \mathrm{~m}$ wide at the highwall to $3.3 \mathrm{~m}$ wide at a penetration depth of $50 \mathrm{~m}$.

The subsidence was apparently caused by the failure of 12 pillars, which had widths ranging from $2.8 \mathrm{~m}$ to $7 \mathrm{~m}$. To analyze the instability, it was necessary to investigate the strength of a pillar of various widths.

The pillar strength was investigated numerically using UDEC. The mechanical properties listed in Table 3 were used as the base case for this study. The following variations from the base case were investigated:

Case 1. Designed entry geometry.

Pillar/entry height $=2.8 \mathrm{~m}$, and coal layer of $0.6 \mathrm{~m}$ was left in the roof and floor. This is an ideal case configuration which the mining operators tried to achieve. It is uncertain how well this was achieved during actual mining. Coal falls and cutting into the high ash floor were reported in the mining record.

Case 2: Entry geometry after roof falls.

Pillar/entry height $=4.8 \mathrm{~m}$. An entry this high could have resulted from mining too close to the floor combined with extensive falls of roof coal and roof claystone. This was likely in the region of subsidence due to the angled roof bedding. Mining records reported regular coal falls during mining in this region. The claystone roof with inclined bedding was shown to be unstable once exposed. Time and water in the entries would have worsened the roof falls.

Case 3: Entry geometry after roof falls and time effect.

Pillar/entry height $=4.8 \mathrm{~m}$, and the strength of the intensive coal joints was reduced due to time and water effect. It is considered that this case represents the most likely scenario. A cohesion of $0.1 \mathrm{MPa}$ and friction angle of $33^{\circ}$ were estimated in the design report for the inclined coal joints through the seam. This estimate may reflect the in situ strength conditions. More than one year after mining, particularly after the entries were flooded, the coal joints would be expected to have lost their cohesion and their friction angle might have been reduced. A zero cohesion value and a friction angle of $30^{\circ}$ were used in Case 3. A number of pillar sizes were modeled for all the three cases. The results are summarised in Table 4 and plotted in Figure 11.

As expected, the pillar strength in Case 1 is the highest among all the three cases. When the pillar height increases from

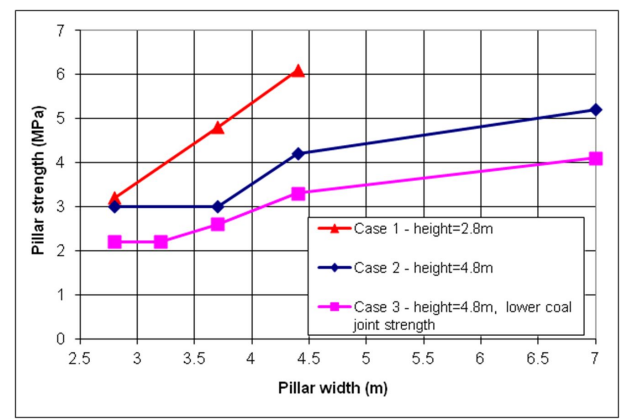

Figure 11. Variations of pillar strength with pillar width for three different cases.

$2.8 \mathrm{~m}$ for Case 1 to $4.8 \mathrm{~m}$ in Cases 2 and 3 , the pillar strength for a given pillar width $(>3.0 \mathrm{~m})$ is found to reduce significantly (compare the three curves in Figure 11.)

In Case 2, a pillar strength of $3 \mathrm{MPa}$ is obtained for pillars $\leq 3.7 \mathrm{~m}$ wide. This strength is equal to the mass coal UCS used in the modeling. This result suggests that the effect of the coal joints with the particular strengths that were assigned have only a minor effect on pillar strength. In Case 3, which was formulated to simulate the effects of time and water, the calculated pillar strength is found to reduce by up to $30 \%$, based on the assumed reduction of the strength of the intensive coal joint. This reduction is significant and based on purely theoretical considerations requires a minimum design FOS of 1.4 to achieve a medium term pillar stability. 


\subsection{Panel stability}

Having evaluated individual pillar strength under various mining scenarios the next phase of the investigation was to evaluate overall panel strength. The Limit Equilibrium Method was used. The average strength of the panel in the subsided area can be calculated from the individual pillar strengths obtained above in Case 3. The average panel strength is calculated in a number of $2 \mathrm{D}$ vertical sections parallel to the highwall and at used in the calculation of FOS. The upper bound of the range is the maximum principal stress and the lower bound is the vertical stress. These values were taken from the numerical modeling results. As a result, a range of FOS was obtained and is given in Table 5. The true FOS should lie within the given range.

Figure 12 presents the FOS variation with penetration distance for the failed panel for Case 3 conditions. It shows that the FOS reaches a minimum at a penetration

Table 5. Calculated average panel strength and Factor of Safety (FoS) in the subsided area.

\begin{tabular}{|c|c|c|c|c|c|c|}
\hline $\begin{array}{l}\text { Penetrati } \\
\text { on }(\mathrm{m})\end{array}$ & $\begin{array}{l}\text { In-panel } \\
\text { pillar width } \\
\text { (m) }\end{array}$ & $\begin{array}{c}\text { Barrier } \\
\text { pillar width } \\
\text { (m) }\end{array}$ & $\begin{array}{c}\text { Failed } \\
\text { panel } \\
\text { width } \\
(\mathrm{m}) \\
\end{array}$ & $\begin{array}{l}\text { Average } \\
\text { panel } \\
\text { strength } \\
(\mathrm{MPa}) \\
\end{array}$ & $\begin{array}{c}\text { Actual } \\
\text { stress } \\
(\mathrm{MPa}) \\
\left(\sigma_{\mathrm{v}}, \sigma_{1}\right) \\
\end{array}$ & FoS \\
\hline 0.00 & \multirow{2}{*}{\multicolumn{6}{|c|}{$\begin{array}{l}\text { Penetration depth less than } 10 \mathrm{~m} \text { is excluded in this calculation because the plane strain } \\
\text { assumption used in the study is no longer valid. }\end{array}$}} \\
\hline 5.00 & & & & & & \\
\hline 10.00 & 2.90 & 6.39 & 70.0 & 1.19 & 0.94-1.13 & $1.06-1.27$ \\
\hline 15.00 & 2.95 & 6.08 & 63.7 & 1.20 & $0.99-1.15$ & $1.01-1.22$ \\
\hline 20.00 & 3.00 & 5.78 & 57.4 & 1.22 & $1.03-1.29$ & $0.98-1.18$ \\
\hline 25.00 & 3.05 & 5.47 & 51.0 & 1.24 & $1.09-1.31$ & $0.94-1.13$ \\
\hline 30.00 & 3.10 & 5.17 & 44.4 & 1.26 & $1.16-1.42$ & $0.88-1.08$ \\
\hline 35.00 & 3.15 & 4.86 & 37.8 & 1.28 & $1.24-1.48$ & $0.87-1.03$ \\
\hline 40.00 & 3.20 & 4.55 & 31.1 & 1.32 & $1.26-1.51$ & $0.88-1.05$ \\
\hline 45.00 & 3.26 & 4.25 & 24.3 & 1.38 & $1.31-1.45$ & $0.95-1.06$ \\
\hline 50.00 & 3.31 & 3.94 & 17.4 & 1.45 & $1.35-1.45$ & $1.00-1.08$ \\
\hline 55.00 & 3.36 & 3.64 & 10.4 & 1.57 & $1.38-1.46$ & $1.08-1.14$ \\
\hline
\end{tabular}

various penetration depths, using the following formula.

AveragePanelStrength $=\frac{\sum(\text { PillarWidth } \times \text { PillarStrength })}{\text { PanelWidth }}$

After calculating the average panel strength, the FOS at a specific penetration depth can then be obtained by using the loading stress. Here both the vertical stress and the maximum principal stress have been used.

$$
\text { FoS }=\frac{\text { AveragePanelStrength }}{\text { ActualStress }}
$$

The results are summarized in Table 5 and plotted in Figure 12. Table 5 provides ranges of actual stress values that were

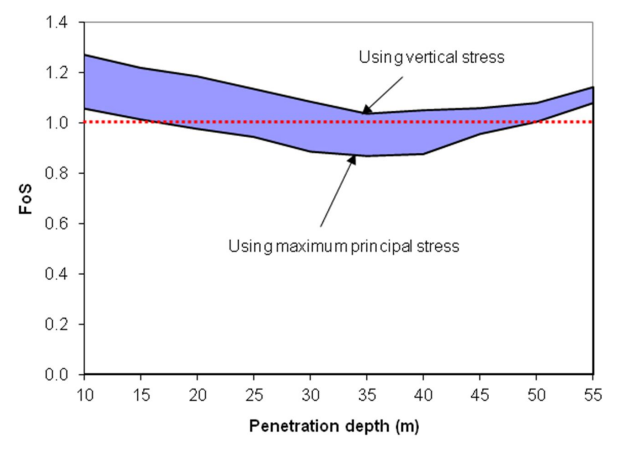

Figure 12. Variations of Factor of Safety (FoS) with penetration depth in the subsided area

distance of $35 \mathrm{~m}$, and the minimum FOS is predicted to be in the range 0.87-1.03. At a penetration distance of $15-50 \mathrm{~m}$, if 
the maximum principal stress is used, the FOS is predicted to have fallen below 1.0. Judging from the plot of FOS presented in Figure 12, it is believed that the subsidence started at about $30-40 \mathrm{~m}$ inbye, which is just behind the top bench of the highwall. The failure propagated both toward the highwall and deeper into the panel. But due to stronger confinement deeper in the reserve, the extent of the subsidence was further toward the highwall than into the panel.

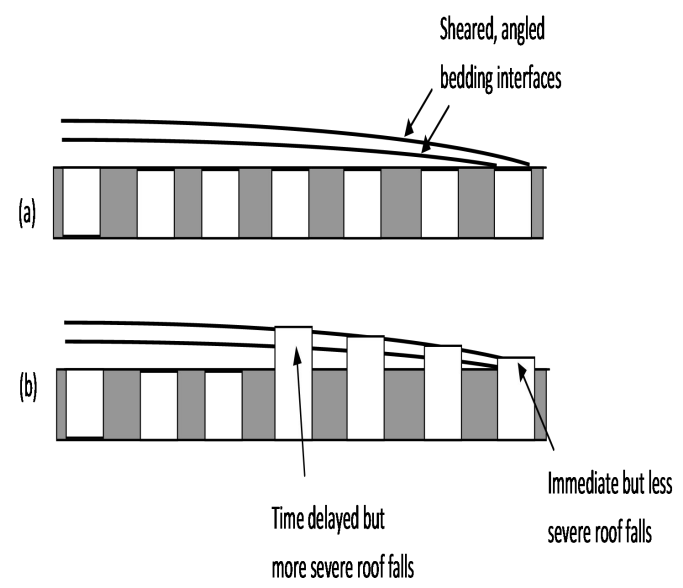

Figure 13. A sketch drawing of roof fall mechanism. Roof falls of different sizes occur at different locations due to angled roof bedding.

For the analyses of Case 3 a pillar height of $4.8 \mathrm{~m}$ was used. It is believed that the maximum increase in height of the pillars occurred only in the subsided area due to extensive roof falls. In the subsided area, the steeply dipping bedding planes led to the roof falls. The mining records reported that the worst roof falls experienced during mining occurred in Entry 43, towards the northern end of the subsidence zone. The locations of roof falls experienced during mining may reflect the intersection between the angled roof layers and the seam. It is possible that more severe roof falls may have occurred in the area behind the intersection after mining, given that the immediate roof is sheared. It is postulated that some form of progressive failure took place. This mechanism is demonstrated in Figure 13. In Entries 33-42 where the subsidence occurred, although no major roof falls were reported during mining, it is possible that extensive roof falls occurred after mining, which eventually caused the failure.

\subsection{Progressive panel failure}

Previous experience has shown that highwall mining panel failures can occur rapidly, sometimes violently, and often extends throughout the mined panel. The subsidence at Pit B showed the opposite characteristics. It occurred rather slowly (the full subsidence developed over two weeks) and was confined to a limited area. The wide barrier pillar $(7.0 \mathrm{~m})$ is believed to be the key factor for the slow panel failure.

It is known that a wide "fat" barrier pillar behaves quite differently compared with a narrow and "skinny" web pillar. While a skinny pillar often collapses quickly, a fat pillar may fail progressively. This is because the confinement from the roof and floor contact often restricts the volume expansion associated with coal failure, and hence increases the confining stress in the centre of the wide pillar.

It is believed that the failure of the $7.0 \mathrm{~m}$ barrier pillar in Pit B occurred progressively, which in turn led to a progressive panel failure as observed.

\section{Conclusions}

Highwall mining has proven to be an economical yet productive mining method to extract coal from areas which otherwise could not have been reached by 
open-cut or underground operations. It has the potential to extend the life of open cut reserves by many years, yielding many millions of dollars of coal far more economically than recovery by underground technology.

Considerable improvement in highwall mining technology and layout design has been achieved over the past decedes. The research into the geomechanical issues related to highwall mining, particularly in pillar design and span stability assessment, has played a significant role in the successful implementation of this technology.

The case study described in this paper highlights the need for careful consideration of all geotechnical factors during design for a successful highwall option.

The back-analysis results presented above suggested that the subsidence in Pit B might have been caused by three major factors:

Angled roof bedding over a limited area led to severe roof falls, which heightened the pillars and reduced the pillar strength, Water infill into the mined entries contributed to the roof falls and weakened the pillars, mainly by weakening the coal joints, and

Time effects also led to progressive roof falls and pillar weakening, as observed in other highwall failures.

\section{References}

[1] Shen B. and Duncan Mary M.E.. 2001. Geomechanics and Highwall Mining. World Coal, February 2001. Pp.35-38.

[2] Townsend J.M., Jennings W.C., Haycocks C., Neall G.M. \& Johnson L.P. 1977. A Relationship Between the Ultimate Compressive Strength of Cubes and Cylinders for Coal Specimens. Proc. 18th U.S. Symp. On Rock Mech., ed. F. Wang and G.B.
Clark, 4A6-1-4A6-6. Golden: Colorado School of Mines Press.

[3] Kelly M., Duncan Fama M.E., Shen B., Follington I.L. \& Leisemann B.E. 1998. Investigation of Highwall Mining Instability, Pit 16BL South, Moura Mine, QLD. CSIRO Exploration and Mining Report No. 467C (Confidential).

[4] Duncan Fama M.E., Shen B., Craig M.S., Kelly M., Follington I.L. \& Leisemann B.E. 1999. Layout Design and Case Study for Highwall Mining of Coal. Proc. 9th Int. Congr. Rock Mech., Balkema, Rotterdam. 